\title{
Modeling and Mapping Sand Encroachment Risk as an Aid for Urban Planning in the United Arab Emirates (UAE)
}

\author{
Naeema Alhosani \\ Department of Geography and Urban Planning, College of Humanities and Social Sciences, United Arab Emirates University, Al \\ Ain, UAE \\ Email: naeemam@uaeu.ac.ae
}

How to cite this paper: Alhosani, N. (2018) Modeling and Mapping Sand Encroachment Risk as an Aid for Urban Planning in the United Arab Emirates (UAE). Journal of Geographic Information System, 10, 699-717.

https://doi.org/10.4236/igis.2018.106036

Received: October 10, 2018

Accepted: December 11, 2018

Published: December 14, 2018

Copyright $\odot 2018$ by author and Scientific Research Publishing Inc. This work is licensed under the Creative Commons Attribution International License (CC BY 4.0).

http://creativecommons.org/licenses/by/4.0/

\begin{abstract}
Sand encroachment into urban areas represents a high risk factor for transportation infrastructural and urban development in the United Arab Emirates. The UAE is located in one of the world's largest arid regions with a strong prevalence of sand movement and encroachment into urban areas, particularly in the last few years. The objective of this research is to develop a land surface process platform that models sand movements and further generates an encroachment risk index map of potential encroachment risk areas season-wise in the UAE. To achieve this objective, this research used elevation and land cover maps generated from Lands at 8 Operational Land Imager (OLI) data which represent the topography of the study area coupled with meteorological information on wind speed, temperature and precipitation. Furthermore, the study considered the vegetation cover as a major contribution factor to reduce sand encroachment. Using developed sand movement model for this research, sand encroachment risk maps were generated to help urban planners in cities making informed decisions of future urban protection structures and transportation networks that mitigate the effects of sand dunes encroachments in the UAE. A major finding of this research results conclude that during the summer season encroachment risk reaches $30 \%$ higher compared to the winter season due to the extremely high temperature which leads to reduced vegetation in the country. Urban planning decision maker may consider the finding of this research for future infrastructural adjustments.
\end{abstract}

\section{Keywords}

Aeolian Sand, Lands at 8 OLI, Sand Encroachment, Transportation,

Vegetation, Temperature 


\section{Introduction}

In the last few decades, anthropogenic activities and economic development have been significantly impacted by variability of climate. These impacts are strongly linked to the occurrence of geomorphological hazards, such as floods, landslides, snow avalanches, soil erosion, and others [1]. Aeolian sand and sand dunes encroachment into urban areas is a phenomenon occurring in many arid and semi-arid regions of the world. In the past few decades, the phenomenon has been further aggravated by agricultural and industrial activities [2]. The UAE is located on the Southeastern limit of the Arabian Peninsula between latitudes $22^{\circ} 50^{\prime}-26^{\circ} 4^{\prime}$ north, and longitudes $51^{\circ} 5^{\prime}-56^{\circ} 25^{\prime}$ east. The UAE has a total area of approximately $83,600 \mathrm{~km}^{2}$ with major geomorphological features. The UAE landscape is diverse and comprises high mountain regions particularly along the border with Oman, coastal sandy beaches along the Arabian Gulf and the sea of Oman, and vast inland deserts. The UAE deserts cover a significant portion of the total area of the country and are largely dominated by different types and shapes of sand dunes. These sand dunes range from smaller size sand pockets to massive dunes-particularly in the southern part of the country, making them a dominant landscape feature in the UAE.

Aeolian sand dunes cover large areas representing about $10 \%$ of the land between latitude $30^{\circ} \mathrm{N}$ and $30^{\circ} \mathrm{S}$ [3]. Aeolian sand dunes are common in the United Arab Emirates (UAE) because of the country's climate, that is characterized by rare rainfalls, high summer temperatures reaching $50^{\circ} \mathrm{C}$ combined with a lack of vegetation cover, as well as solid wind patterns. The climate of the UAE is extremely arid with sporadic low average rainfall of $110 \mathrm{~mm}$ occurring in winter only. Sand dunes movements occur frequently in the UAE due to the arid land climatic conditions. Sand dune movements expand to new areas as a result of degraded soil and insufficient vegetation cover. The arable land in the UAE represents only 0.5 percent of the total land area of the country $\left(83,600 \mathrm{~km}^{2}\right)$ [4].

In the early 1970s, after the creation of the UAE, the country has embarked on an impressive transformation into a modern state, urbanization and infrastructure development. The country has built a highly sophisticated urban infrastructure, modern cities and towns, and large telecommunication and transportation networks. However, frequent sand dune movements continued to pose a major ongoing environmental challenge facing the newly built urban infrastructure.

The process of sand movement is a common phenomenon in desert regions especially in the Middle East and other African desert regions. The interaction of wind with sand leads to sand particles suspension, causing sand encroachment in and around human settlements. For example, in many parts of the UAE sand encroachment has caused a notable damage to transportation road and highways as a result of continuous accumulation and deposition of sand particles on the asphaltroads.

Sand encroachment into urban areas, transportation networks (Figure 1), si- 
milarly airports and other facilities alsoconsidered a major threat to the country's urban infrastructure. Furthermore, it adds significant pressures on urban and town planners in their decision making regarding future landuse and infrastructure development.

Sand encroachment occurs when sand particles are carried and transported by the action of wind and deposited elsewhere [5]. In the UAE as sand is transported and deposited elsewhere it buries transportation networks, residential buildings, palm trees and agricultural plantations. Various physical factors contribute to the transport of large masses of sand. The key important factors are the availability of dry and bare sand particles, violent blowing winds, absence of vegetation cover leading to smoother land surfaces, and the absence of rainfall. The combination levels of these factors at varying degrees creates different levels of sand encroachment risks. Various studies about sand encroachment in the Arabian Peninsula have attempted to model and map sand and sand dunes movement [6] [7] [8]. However, none of these previous studies considered an integrated spatial and temporal modeling of the sand encroachment as presented in this research. Combining the variables such as topography (i.e. slope), meteorological information on wind speed, temperature and precipitation, and vegetation index within one integrated prediction model represent a valid framework to implement the research analysis as explained below.

The primary purpose of this research is to develop a sand movement model to address such risk that support town and urban planners in their daunting tasks of infrastructure planning, development, maintenance and land use planning. As the UAE continues to develop and expand its urban infrastructure, Information regarding at the areas experiencing different levels of risk of sand encroachment is vitally important. For example, the varying wind speeds within the area create different levels of sand encroachment risks.
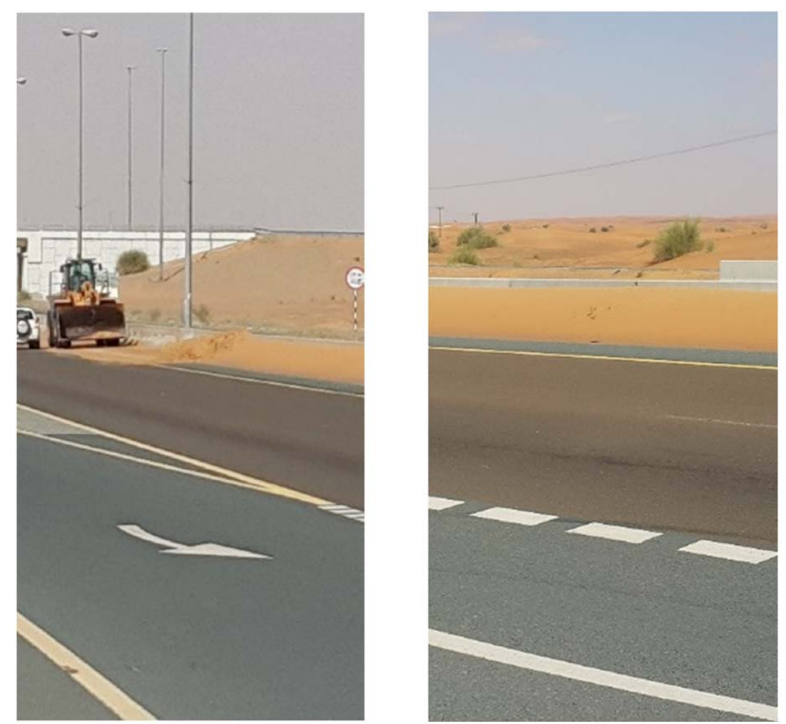

Figure 1. Pictures showing sand encroachment into aldhaid-Al madam highway. 
This research develops a model that attempts to mimic sand movements in the UAE and further classify the areas relative risk of encroachment into urban structures, by the development of arisk index of the potential encroachment in the UAE. The research uses Landsat 8 Operational Land Imager (OLI) data to generate land cover layer coupled with meteorological information such as wind speed, temperature, and rainfall. This set of geospatial and climatological data represents the key environmental factors needed to model an accurate representation of sand movement and encroachment areas. Geospatial technologies offer the possibility of modeling sand encroachment. Such modeling capacities can be used by decision makers to predict the movement of sand dunes, enabling them to accumulate knowledge that can be used in urban planning [9]. Recent advances in remote sensing techniques and geographic information systems technology have made it possible to analyze and study this phenomenon at varying spatial and multi-temporal scales [10]. In addition, such advances will make it possible to analyze and understand the different interactions between the different environmental elements related to sand dunes movement, land use, and human activity. Implementing this approach for mapping active and inactive sand areas using the satellite imagery will enhance analysis and prediction of high-risk areas. Active sand dunes appear brighter than inactive ones and this specific spectral brightness is attributed to higher reflection of electromagnetic radiation [11] [12] [13].

\section{Study Area}

The study area is located on the eastern part of the emirates of Abu Dhabi and Sharjah encompassing the cities of Al Ain, Nahil, Al Shuwib, Al Madam and Al Dhaid (Figure 2). This area, in particular, is prone to sporadic sand movement and encroachment into urban areas and transportation networks. Furthermore, while the area is dominated by desert surfaces, it still has diverse land cover types [14] [15] [16]. In addition to the desert surfaces, there are mountain series along the border with Oman, urban residential areas and date palm trees and vegetable farms representing economic development occurring in the study area. The total area of study area is $11,479 \mathrm{Sq}$. Km.

\section{Data}

The Landsat 8 OLI scene (path 160 and row 43) acquired on July 24, 2015 that covers the study area, was downloaded from the United States Geological Survey (USGS), Earth Resources Observation and Science (EROS) Center (http://earthexplorer.usgs.gov/). The LANDSAT 8 OLI scene covers a large area of the UAE land. It was found necessary to crop the scene and focus on the study area only. The six reflective spectral bands covering the visible, near-infrared (NIR) and short waveinfrared were used in this study.

Meteorological observations covering the study area were obtained from the weather stations within the study area. The stations were operated by the UAE 


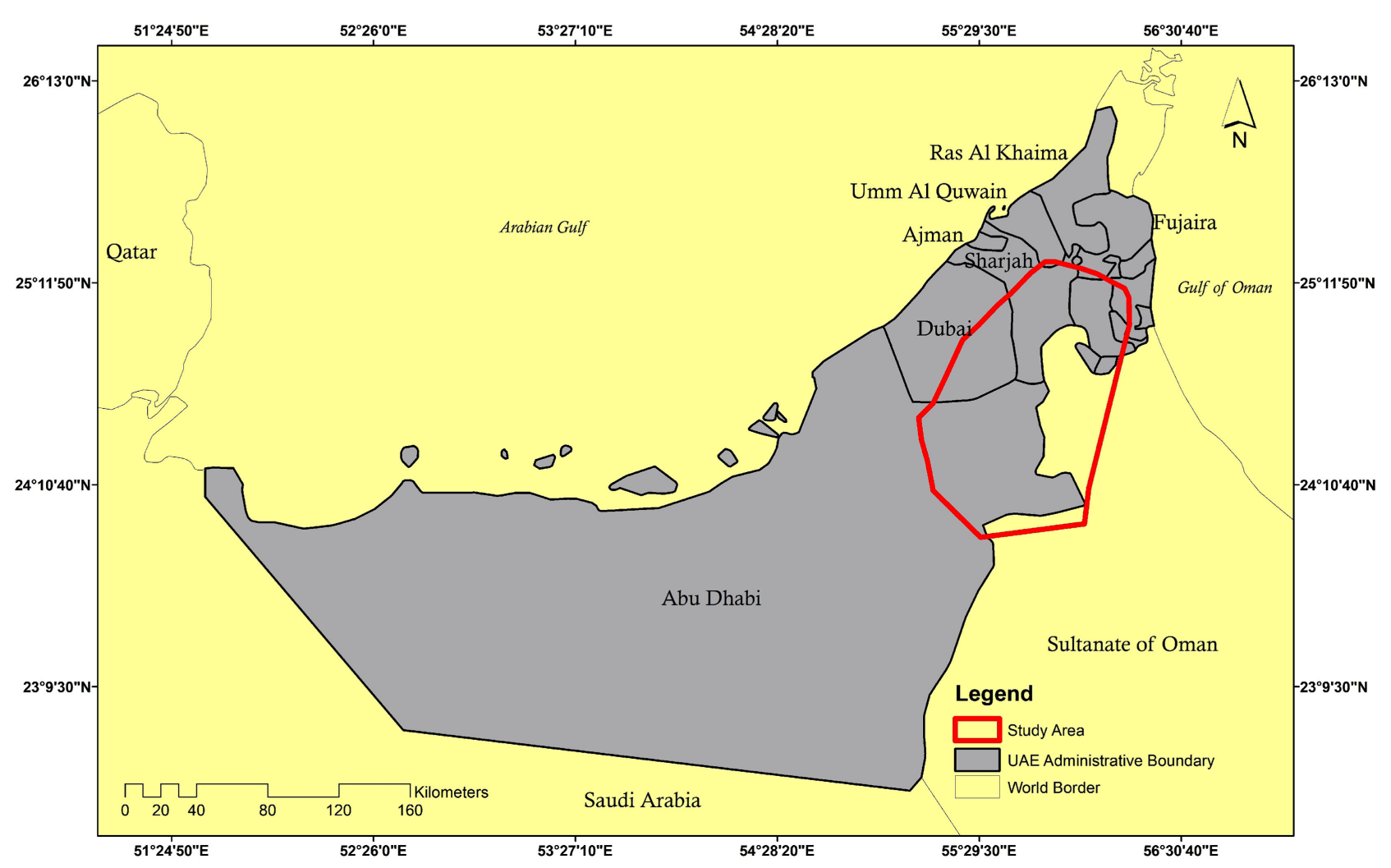

Figure 2. Map of the study area.

National Center of Meteorology and Seismology (http://www.ncms.ae/en/). The study area encompasses five weather stations distributed within the whole area (Figure 3). The data obtained for the months of January, April, July and October 2015 from these stations represented the average monthly daily temperature, average rainfall, and average wind speed.

\section{Methodology}

Six parameters listed in Table 1 was used for grouping and implementation of the modeling of sand encroachment. These parameters are slope, NDVI, rainfall, temperature, wind speed, and soil. Layers were given weight percentage based on factors influencing sand encroachment and they were also ranked according to probability of causing sand encroachment. The highest weight percentage were assigned for soil is $30 \%$ because, the soil roughness is one of important factor affecting the sand movements [17]. The second highest weight percentage was given for wind speed i.e. $25 \%$. The other remaining factors like slop, NDVI rainfall, and temperature the weight percentage was given $20 \%, 15 \%, 7 \%, 3 \%$ respectively.

The soil types found in the study area are Aeolian Sand, Calcareous Sand, Sand and Gravel, Rock outcrop. According the possibility of sand encroachment, we have categorized them into high, medium, low and very low and also ranked them. Similarly, other parameters (Slope, NDVI, rainfall, temperature and wind 
speed) were reclassified into the 5 classes and ranked them accordingly to very low, low, medium, high and very high. Table 2 shows weight percentage and ranks for each layer.

Figure 4 showing the methodology process describes all the processing and analysis that have been conducted to fulfill the objectives of this research. The figure depicts the process of data gathering, analysis, producing targeted indices, reclassification, apply weights and ranks. Three types of datasets were used for the sand encroachment risk mapping of the study area. The first dataset is satellite imagery. The second data set is the elevation data such as Digital Elevation Model (DEM). The third data set is the seasonal climatic data (obtained from the National Centre for Climate and Seismology (NCCS)) for the months of January, March, July and October. These data were recorded from weather stations namely Al Malaiha, Al Shiweb, Alain Airport, Al Dhaid, and Hatta. Figure 5 describes the important process of sand dune encroachment risk index calculation in model builder.

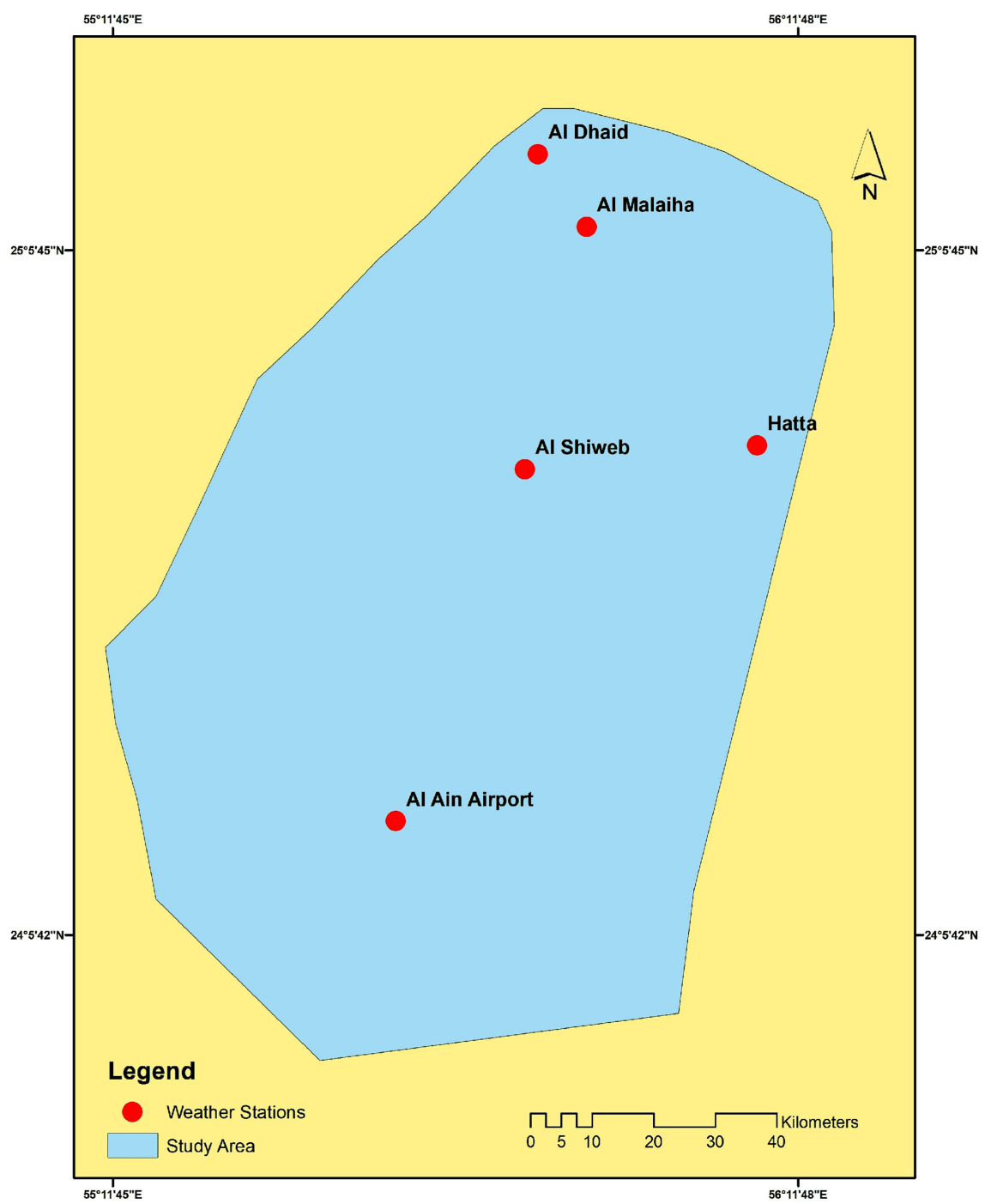

Figure 3. Distribution of weather stations in the study area. 


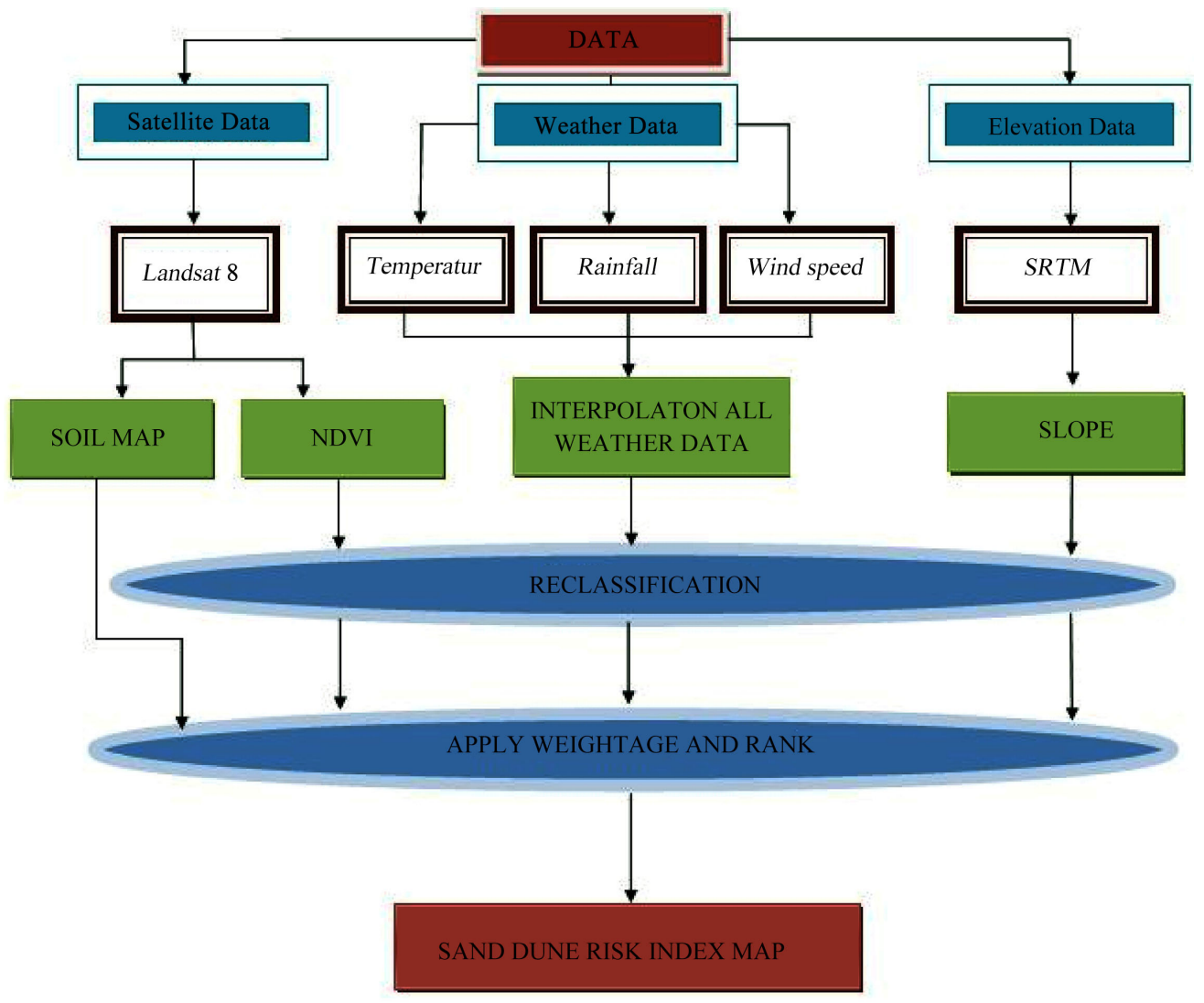

Figure 4. Methodology flow diagram mapping sand encroachment risk areas.

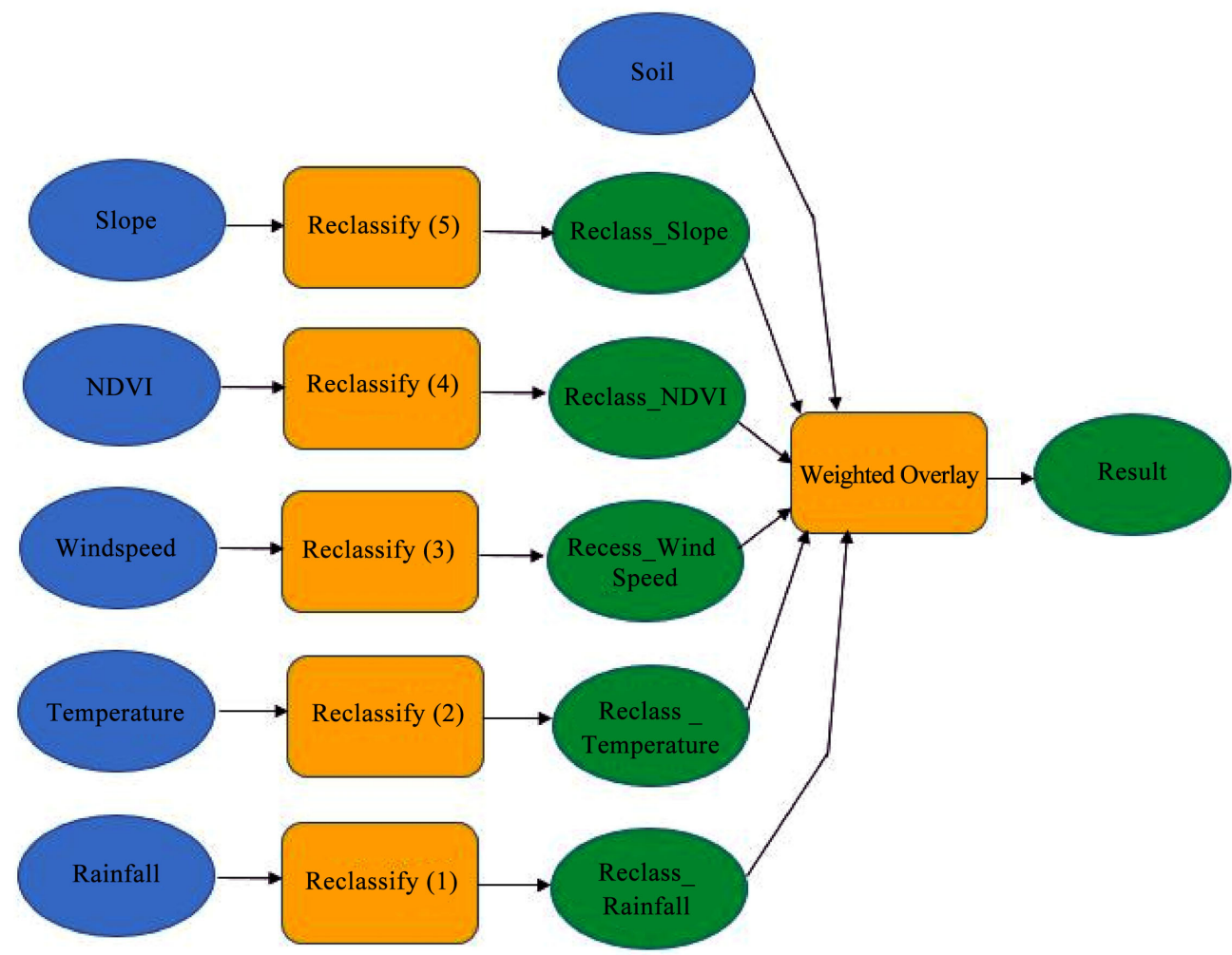

Figure 5. The workflow of used geo-processing in model builder. 
Table 1. Weights and ranks of layers based on their influence in sand encroachment.

\begin{tabular}{|c|c|c|c|c|c|}
\hline \multicolumn{6}{|c|}{ Soil $=30 \%$} \\
\hline Type of Soil & \multicolumn{2}{|c|}{ Possibility of sand Encroachment } & \multicolumn{3}{|c|}{ Ranks } \\
\hline Aeolian Sand & \multicolumn{2}{|c|}{ High } & \multicolumn{3}{|c|}{5} \\
\hline Calcareous Sand & \multicolumn{2}{|c|}{ Medium } & \multicolumn{3}{|c|}{4} \\
\hline Sand and Gravel & \multicolumn{2}{|c|}{ Low } & \multicolumn{3}{|c|}{3} \\
\hline Rock outcrop & \multicolumn{2}{|c|}{ Very Low } & \multicolumn{3}{|c|}{2} \\
\hline \multicolumn{6}{|c|}{ Slope $=20 \%$} \\
\hline Level of Slope & \multicolumn{2}{|c|}{ Possibility of sand Encroachment } & \multicolumn{3}{|c|}{ Ranks } \\
\hline $0-1,952,658.89$ & \multicolumn{2}{|c|}{ Very Low } & \multicolumn{3}{|c|}{1} \\
\hline $1,952,658.9-3,626,366.59$ & \multicolumn{2}{|c|}{ Low } & \multicolumn{3}{|c|}{2} \\
\hline $3,626,366.6-5,579,025.49$ & \multicolumn{2}{|c|}{ Medium } & \multicolumn{3}{|c|}{3} \\
\hline $5,579,025.5-8,368,538.29$ & \multicolumn{2}{|c|}{ High } & \multicolumn{3}{|c|}{4} \\
\hline $8,368,538.3-35,566,288$ & \multicolumn{2}{|c|}{ Very High } & \multicolumn{3}{|c|}{5} \\
\hline \multicolumn{6}{|c|}{$\mathrm{NDVI}=15 \%$} \\
\hline Level of Vegetation & \multicolumn{2}{|c|}{ Possibility of sand Encroachment } & & Ranks & \\
\hline$-0.156-0.052$ & & y High & & 5 & \\
\hline $0.053-0.085$ & & High & & 4 & \\
\hline $0.086-0.128$ & & edium & & 3 & \\
\hline $0.129-0.211$ & & Low & & 2 & \\
\hline $0.212-0.525$ & & ry Low & & 1 & \\
\hline & & Rainfall $=7 \%$ & & & \\
\hline $\begin{array}{l}\text { Intensity of Rainfall } \\
\text { (January) }\end{array}$ & $\begin{array}{c}\text { Intensity of } \\
\text { Rainfall (April) }\end{array}$ & $\begin{array}{c}\text { Intensity of Rainfall } \\
\text { (July) }\end{array}$ & $\begin{array}{l}\text { Intensity of Rainfall } \\
\text { (October) }\end{array}$ & $\begin{array}{l}\text { Possibility of sand } \\
\text { Encroachment }\end{array}$ & Ranks \\
\hline $0.400-5.597$ & $0.000-3.278$ & $0.00000094-5.185$ & $0.000-0.696$ & Very High & 5 \\
\hline $5.598-9.025$ & $3.279-6.079$ & $5.186-10.508$ & $0.697-1.298$ & High & 4 \\
\hline $9.026-13.449$ & $6.080-8.285$ & $10.509-15.967$ & $1.299-2.108$ & Medium & 3 \\
\hline $13.450-19.752$ & $8.286-10.967$ & $15.968-23.063$ & $2.109-3.256$ & Low & 2 \\
\hline $19.753-28.599$ & $10.968-15.140$ & $23.064-34.799$ & $3.257-4.799$ & Very Low & 1 \\
\hline & & Temperature $=3 \%$ & & & \\
\hline $\begin{array}{c}\text { Intensity of Temperature } \\
\text { (January) }\end{array}$ & $\begin{array}{c}\text { Intensity of } \\
\text { Temperature (April) }\end{array}$ & $\begin{array}{c}\text { Intensity of } \\
\text { Temperature (July) }\end{array}$ & $\begin{array}{c}\text { Intensity of } \\
\text { Temperature (October) }\end{array}$ & $\begin{array}{l}\text { Possibility of sand } \\
\text { Encroachment }\end{array}$ & Ranks \\
\hline $17.100-17.354$ & $28.402-29.012$ & $34.388-35.058$ & $28.977-29.446$ & Very Low & 1 \\
\hline $17.355-17.476$ & $29.013-29.368$ & $35.059-35.669$ & $29.447-29.821$ & Low & 2 \\
\hline $17.477-17.620$ & $29.369-29.615$ & $35.670-36.112$ & $29.822-30.076$ & Medium & 3 \\
\hline $17.621-17.755$ & $29.616-29.940$ & $36.113-36.468$ & $30.077-30.337$ & High & 4 \\
\hline $17.756-17.899$ & $29.941-30.372$ & $36.469-36.900$ & $30.338-30.686$ & Very High & 5 \\
\hline & & Wind Speed $=25 \%$ & & & \\
\hline $\begin{array}{l}\text { Intensity of Wind speed } \\
\text { (January) }\end{array}$ & $\begin{array}{l}\text { Intensity of Wind } \\
\text { speed (April) }\end{array}$ & $\begin{array}{l}\text { Intensity of Wind speed } \\
\text { (July) }\end{array}$ & $\begin{array}{l}\text { Intensity of Wind speed } \\
\text { (October) }\end{array}$ & $\begin{array}{l}\text { Possibility of sand } \\
\text { Encroachment }\end{array}$ & Ranks \\
\hline $6.000-7.482$ & $7.860-9.342$ & $10.069-11.311$ & $9.001-10.346$ & Very Low & 1 \\
\hline $7.483-8.690$ & $9.343-10.593$ & $11.312-12.281$ & $10.347-11.103$ & Low & 2 \\
\hline $8.691-10.200$ & $10.594-11.820$ & $12.282-13.174$ & $11.104-11.823$ & Medium & 3 \\
\hline $10.20-11.545$ & $11.821-12.944$ & $13.175-13.892$ & $11.824-12.657$ & High & 4 \\
\hline $11.546-12.972$ & $12.945-14.375$ & $13.893-15.017$ & $12.658-13.831$ & Very High & 5 \\
\hline
\end{tabular}


Table 2. Areas and Percentage of sand encroachment during different months.

\begin{tabular}{ccccccccc}
\hline \multirow{2}{*}{ Months } & \multicolumn{7}{c}{ Total Area $=11479$ Sq. Km } \\
\cline { 2 - 10 } & \multicolumn{2}{c}{ Low } & \multicolumn{2}{c}{ Medium } & \multicolumn{2}{c}{ High } & \multicolumn{2}{c}{ Other } \\
\hline & Sq. Km & $\%$ & Sq. Km & $\%$ & Sq. Km & $\%$ & Sq. Km & $\%$ \\
\hline January & 1448.78 & 12.62 & 6147.45 & 53.55 & 1394.88 & 12.15 & 2487.9 & 21.6 \\
April & 1306.59 & 11.38 & 6621.58 & 57.68 & 1062.96 & 9.26 & 2487.9 & 21.6 \\
July & 672.89 & 5.86 & 4851.51 & 42.26 & 3466.74 & 30.2 & 2487.9 & 21.6 \\
October & 742.92 & 6.47 & 6046.74 & 52.67 & 2201.46 & 19.17 & 2487.9 & 21.6 \\
\hline
\end{tabular}

The land cover types in the study area included a mountain range between Oman and the UAE, rock outcrops, urban residential areas, scattered plantations of date palm and vegetables, transportation networks and different sand types. Of particular importance here are the different sand types within the study area. There are three different types represent the major surfaces that provide varying amounts of sand for the wind to transport and distribute within the study area.

The sand and gravel land cover type which provides smaller amounts of sand to be transported by the wind action has been deemed to be the area with the lowest risk for sand movement. The movement of the sand from one to other land cover is usually slowed significantly by the presence of the gravel pieces which come in different sizes. Aeolian sand covers the major dunes in the area and usually contains more iron oxide giving it a reddish color [18]. Also, this type of sand encompasses a low level of calcareous and silica and has a much finer sand particle size that is easy to transport. Calcareous sand contains huge amounts of calcium carbonates. It also covers the salt flats deposits located in close proximity to the coasts. The calcareous sand particles are usually transported from coastal regions by means of wind, water, and through evaporate deposit. It is usually found closer to the coastal areas and decreases towards the sand dunes areas. Its sand particles are much slower to move in comparison to the sand particles in aeolian sand types. Figure 6 shows the land cover map for the study area resulting from the classification process.

The meteorological data represented the mean monthly values of temperature, wind speed, and rainfall. An interpolation process was carried out to generate wind speed, temperature and rainfall layers for the study area using the data from the five climate weather stations. Interpolation process helps to predict the value of the attribute at unsampled sites from measurements made at point locations within the same area or region.

The applied IDW interpolation method helps to estimate cell values by averaging the values of sample data points in the neighborhood of each processing cell. IDW Interpolation method assumes that the characteristics of the surface are driven by local variation. It works best if the sample points are not clustered but evenly distributed throughout the area. The closer a point is to the center of the cell being estimated, the more influence, or weight it has in the averaging process. 


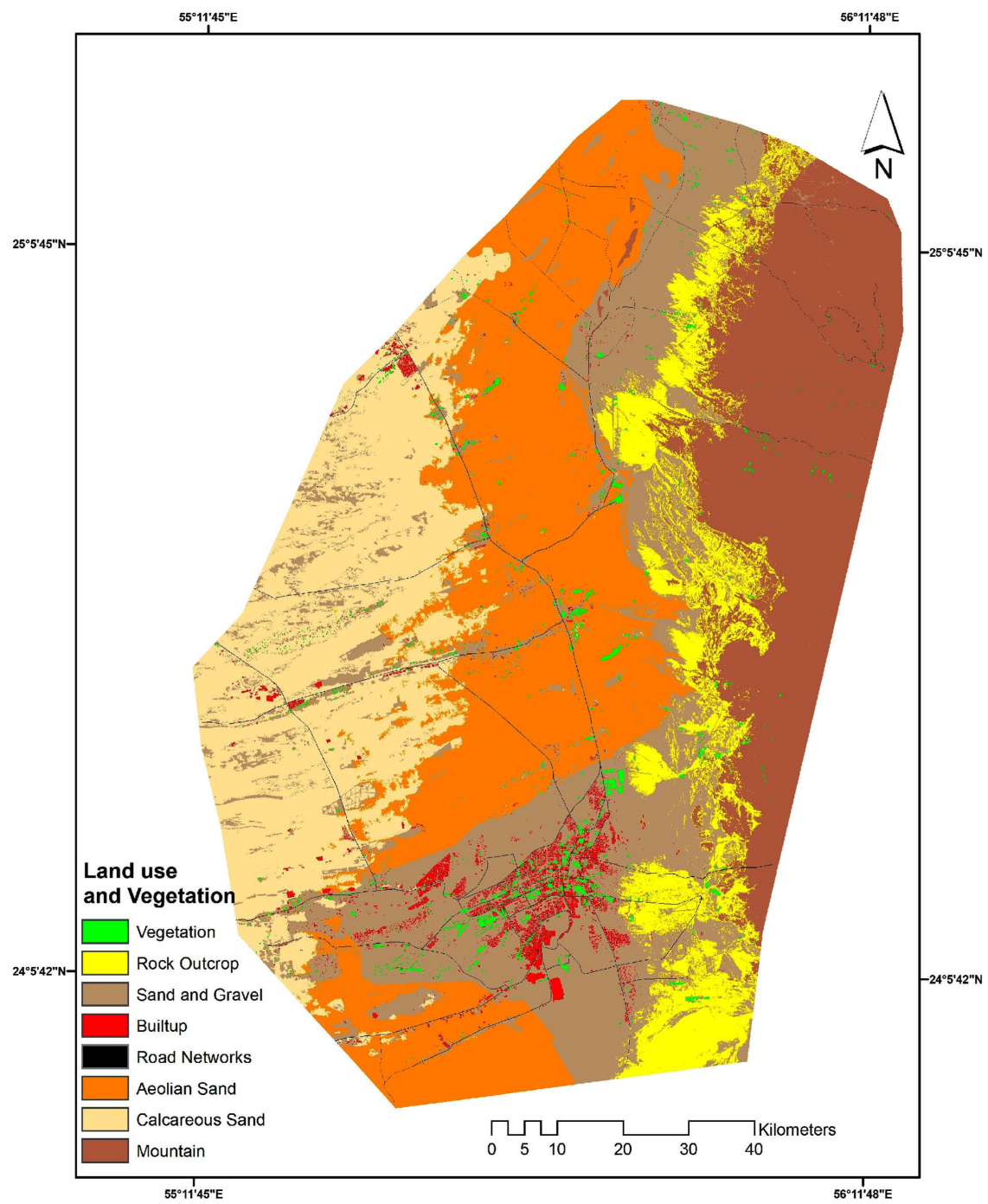

Figure 6. Land cover types of the study area.

The model developed here identifies the level of risk using the varying magnitudes of the key factors that act on sand transport. Careful observations of the land cover within the study area is needed for quantifying the intensity of sand encroachment. Aeolian sand is the potential source for major sand movement, with calcareous sand being the one with the medium level of sand movement. Areas of sand and gravel represent the land cover where the potential of sand movement is the lowest. The four months January, April, July and October were selected in this study to reflect the four seasons Winer, Spring, extremely hot Summer, and warm summer respectively in the arid region of UAE.

The mere presence of sand particles is not the only driving factor for sand movement because the power of any wind to erode or move sand particles, upwards or downwards, is primarily controlled by two major factors. The first factor is related to the speed of the wind moves and its ability to move sand. The second factor is the surface roughness within the study area which is dependent on the vegetation plantations and the presence or absence of wet sand. Vegeta- 
tion cover act as a barrier and significantly reduce the ability of wind to move sand. Sand movement after a rainfall episode is also significantly reduced as the sand particles get clumped and compacted together.

Varying degrees of violent blowing winds, the absence of vegetation cover, and the absence of rainfall (or wet sand) are the primary factors to delineate the area of being a high, medium or low risk for sand movement within the different land cover types. Physical geography defines threshold velocity as the velocity required to cause entrainment in the erosional agents of wind.

\section{Results and Discussion}

The three sand movement risk zones (High, Medium and Low) were generated for the months of January, April, July and October, 2015. As per the month January is considered, the area covered by the low, medium, high-risk zone, contributes $1448.78,6147.45,1394.88 \mathrm{~km}^{2}$ which makes $12.62 \%, 53.55 \%, 12.15 \%$ respectively of the total study area. For the spring month of April 2015, the area of low sand movement risk zone was found to be $1306.59 \mathrm{~km}^{2}$ (11.38\%). This shows that low-risk area decreased in April compared to January. The area of medium-risk zone for April was found to be $6621.58 \mathrm{~km}^{2}$ (57.68\%). The areas showed an increase compared to the month of January for the medium-risk zone. The high-risk zone area in this month was $1062.96 \mathrm{~km}^{2}(9.26 \%)$ indicating a decrease compared to January.

For the assessment in the month of July, and looking into all the sand encroachment zones changed in this extreme summer month, we can find the high-risk zone has reached $3466.74 \mathrm{~km}^{2}$ showing $30.2 \%$ of the total area. This is highest value compared with the high-risk zone of all other three months considered. The low and medium risk zone area in this month is 672.89 (5.86\%), 4851.51 (42.26\%) respectively.

The analysis carried out on the month of October showedlow-risk zone was $742.92 \mathrm{~km}^{2}$ which is about $6.47 \%$ of the total area. The medium and high-risk zone in this month was $6046.74 \mathrm{~km}^{2}$ and $2201.46 \mathrm{~km}^{2}$ it contributes 52.67 and $19.17 \%$ respectively of the total area. Table 2 shows monthly (Seasonal) wise sand encroachment by areas and their percentage.

Figure 7 shows the sand encroachment maps of January, April, July, and October 2015. The yellow color in these maps depicts the low-risk zone, which mainly occupied the northern part of the study area. The blue color shows the Medium risk zone areas and it is mainly seen in the western and northwestern parts of the study area. The red color in the map shows the sand high-risk zone and it is mainly in the central and southern part of the study area. The study reveals that the surface roughness and weather are the important factors affecting the sand movement. Wherever Aeolian sand, high wind speed, high temperature, and low rainfall are there, there will be a high possibility of sand movement.

The results demonstrated the accuracy of the model in identifying various levels of sand movement areas within both sand cover types. The areas within the 


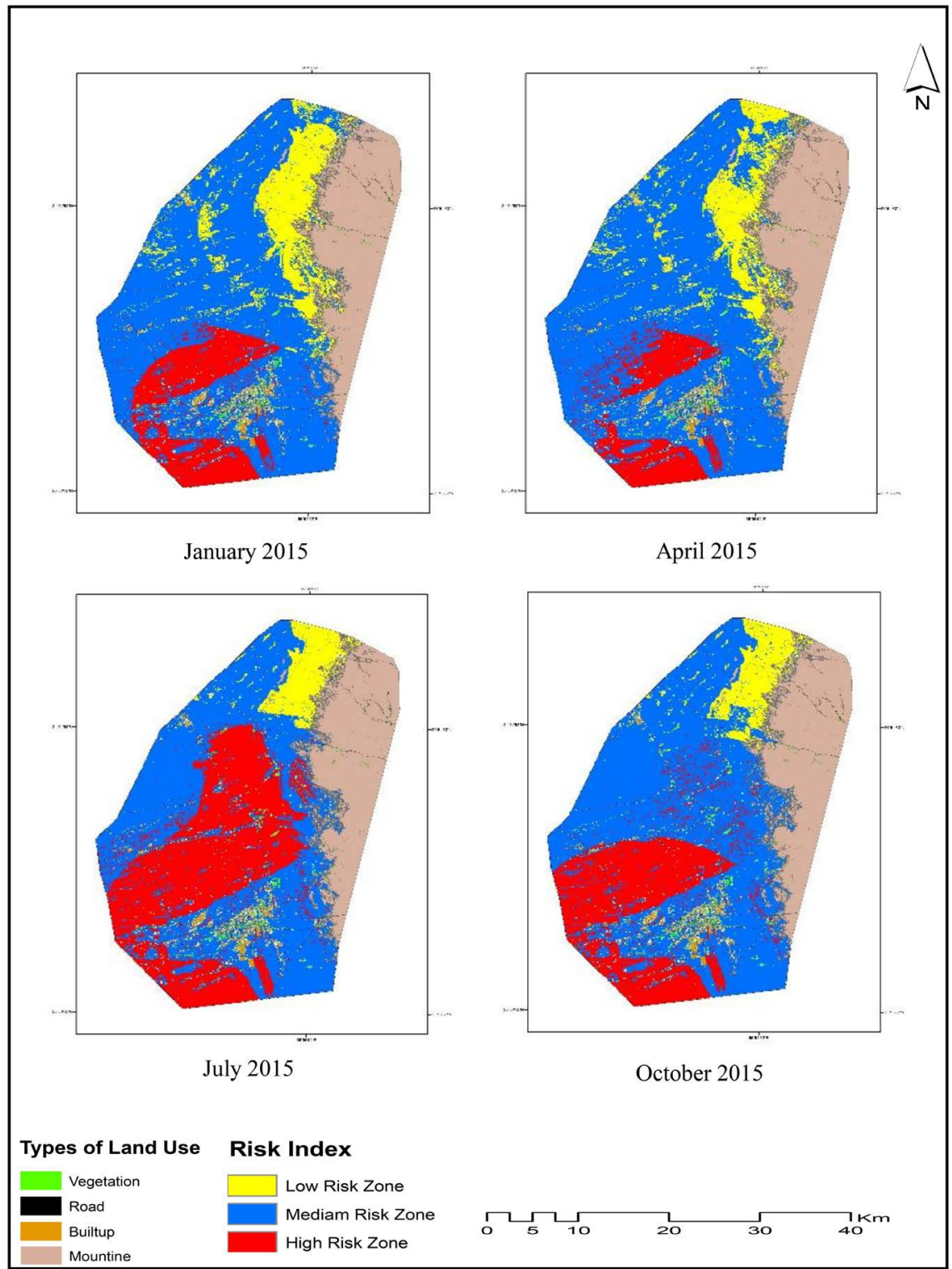

Figure 7. Sand movement developed risk zones.

center of the study area represent the major dune areas and aeolian sand. This area is usually open to the action of wind with little to no major structures acting as a barrier for sand movement. Medium risk areas for both sand classes are characterized by the presence of scattered palm and agricultural plantations. The model was able to calculate these areas as being at a lower risk for sand movement, indicating a high surface roughness that slows sand movement.

The model worked effectively in identifying areas of high, medium and low risks using key parameters such as wind speed, temperature, rainfall, NDVI, soil, and slope. The model was applied to only four-month worth of meteorological data as a proof of concept. However, to overcome the study limitation it is necessary to have more integrated and enhanced study using wind pattern and dynamics. Further investigations are planned to finely tune the model for more 
improvements through the incorporation of other surface and meteorological parameters. In the future, the model will be improved further through the introduction of seasonal variations of the wind speed pattern, temperature, rainfall, the slopes, orientations and sizes of sand dunes, as well as sand particle size and humidity. It is believed that through the introduction of these parameters, better and much more accurate risk maps can be generated to aid in the process of urban planning in the UAE.

\section{Conclusions}

In this study we have developed sand movement models for the surfaces in UAE. This was produced according to the factors like wind speed, temperature, precipitation, vegetation and surface roughness of the study area to identify and produce the map i.e. high, medium, and low-risk sand movement areas. The significance of this study shows that during summer season UAE witnessed the high sand encroachment. About 30\% of the total area is found high sand encroachment in the months of January, April, July, and October to reflect the four seasons of Winter, Spring, extreme Summer, and warm Summer respectively. The results of this research found that during the month of July when temperature is high and vegetation is reduced the risk index reaches its highest level of 30\% higher compared to the risk during the winter season in January. This is due to the fact during such extremely high temperature, in the summer the study area is not suitable for any agricultural practices. This proves that vegetation and season play a major role in sand encroachment in the areas studied.

Thus, this work finding indicates to the urban planners to take proper decision for the aid of infrastructure growth. During the last few decades, there has been tremendous urban development in the UAE. For instance, in the building of major urban facilities, transportation networks and airports, such risk maps are vitally important and provide a powerful planning tool for urban planners and municipal plans. Through the incorporation of such information in the future planning processes, informed and accurate decisions can be taken to avoid high-risk sand encroachment areas. Such decision may consider the unique temporal and spatial variability in the study area. This research offers findings in connection to four climatic seasons in the study area.

This research faced the challenge of modelling demand for large data sets to represents more detailed temporal dimension across time. For search reason the author offered month by month data on topography, weather condition, and vegetation in Appendix A and $\mathrm{B}$. This is to enable further studies on modeling and mapping sand encroachment for risk analyses.

\section{Acknowledgements}

This research work was supported by a grant from the National Research Fund in Abu Dhabi. The author would like to extend her appreciation for the assistance and support given by Dr. Khalid Hussein, Dr. Eihab Fathelrahman and 
Mr. Safwan Paramban, United Arab Emirates University for their review of manuscript and their valuable inputs. This research acknowledges the support of Dr. Abdelgadir Abuelgasimas he offered an initial framework for this research.

\section{Conflicts of Interest}

The author declares no conflicts of interest regarding the publication of this paper.

\section{References}

[1] Ayala, I.A. and Goudie, A.S., Eds. (2010) Geomorphological Hazards and Disaster Prevention. Cambridge University Press, 2010.

[2] Kemp, R.L. and Stephani, C.J., Eds. (2013) Global Models of Urban Planning.

[3] Sarnthein, M. (1978) Sand Deserts during Glacial Maximum and Climatic Optimum. Nature, 43-46. https://doi.org/10.1038/272043a0

[4] Food and Agricultural Organization (FAO). http://www.fao.org/faostat/en/\#data/RL

[5] Bagnold, R.A. (1941) The Physics of Blown Sand and Desert Dunes. Methuen, London.

[6] Al-Dousari, A.M. and Pye, K. (2005) Mapping and Monitoring of Sand Dunes in Northwestern Kuwait. Kuwait Journal of Science and Engineering, 32, 119-134.

[7] Al-Awadhi, J.M., Al-Hellal, A. and Al-Enezi, A. (2005) Sand Drift Potential in the Desert of Kuwait. Journal of Arid Environments, 63, 425-438. https://doi.org/10.1016/j.jaridenv.2005.03.011

[8] Al-Awadhi, J.M., Al-Dousari, A. and Al-Enezi, A. (2000) Barchan Dunes in the Northern Kuwait. Arab Journal of Scientific Research, 18, 32-40.

[9] Abdel-Aziez, S.M., Eweda, W.E., Girgis, M.G.Z. and Ghany, B.F.A. (2014) Improving the Productivity and Quality of Black Cumin (Nigella sativa) by Using Azotobacter as N 2 Biofertilizer. Annals of Agricultural Sciences, 59, 95-108. https://doi.org/10.1016/j.aoas.2014.06.014

[10] Fadhil, A.M. (2013) Sand Dunes Monitoring Using Remote Sensing and GIS Techniques for Some Sites in Iraq. Proc. SPIE 8762, PIAGENG 2013: Intelligent Information, Control, and Communication Technology for Agricultural Engineering, 876206, 19 March 2013.

[11] Collins, W. (1978) Remote Sensing of Crop Type and Maturity. Photogrammetric Engineering and Remote Sensing, 44, 43-55.

[12] Blount II, H.G. (1988) Regional Aeolian Dynamics from Remote Sensing: Origin of the Gran Desierto, Sonora, Mexico. Doctoral Dissertation, Arizona State University.

[13] Thomas, D.S.G. and Leason, H.C. (2005) Dune Field Activity Response to Climate Variability in the Southern Kalahari. Geomorphology, 64, 117-132. https://doi.org/10.1016/j.geomorph.2004.06.004

[14] Farrant, A.R., Arkley, S.L.B., Ellison, R.A., Styles, M.T. and Thomas, R.J. (2006) Geology of Al Hiyar 1:100 000 Map Sheet, 100-3 United Arab Emirates. Ministry of Energy, UAE.

[15] Howari, F.M., Baghdady, A. and Goodell, P.C. (2007) Mineralogical and Geomorphological Characterization of Sand Dunes in the Eastern Part of United Arab Emirates Using Orbital Remote Sensing Integrated with Field Investigations. Geomor- 
phology, 83, 67-81. https://doi.org/10.1016/j.geomorph.2006.06.015

[16] Kirkham, A. (1998) Pleistocene Carbonate Seif Dunes and Their Role in the Development of Complex Past and Present Coastlines of the UAE. GeoArabia, 3, 1998.

[17] Greeley, R., Blumberg, D.G., Dobrovolskis, A.R., Gaddis, L.R., Iversen, J.D., Lancaster, N., et al. (1995) Potential Transport of Windblown Sand: Influence of Surface Roughness and Assessment with Radar Data. In: Desert Aeolian Processes, Springer, Dordrecht, 75-99. https://doi.org/10.1007/978-94-009-0067-7_4

[18] Abu-Zeid, M.M., Baghdady, A.R. and El-Etr, H.A. (2001) Textural Attributes, Mineralogy and Provenance of Sand Dune Fields in the Greater Al Ain Area, United Arab Emirates. Journal of Arid Environments, 48, 475-499.

https://doi.org/10.1006/jare.2000.0776 


\section{Appendix A: Tables}

Table A1. Weights and ranks of layers based on their influence in sand encroachment.

\begin{tabular}{|c|c|c|c|c|c|}
\hline \multicolumn{6}{|c|}{ Soil $=30 \%$} \\
\hline Type of Soil & \multicolumn{2}{|c|}{ Possibility of sand Encroachment } & \multicolumn{3}{|c|}{ Ranks } \\
\hline Aeolian Sand & \multicolumn{2}{|c|}{ High } & \multicolumn{3}{|c|}{5} \\
\hline Calcareous Sand & \multicolumn{2}{|c|}{ Medium } & \multicolumn{3}{|c|}{4} \\
\hline Sand and Gravel & \multicolumn{2}{|c|}{ Low } & \multicolumn{3}{|c|}{3} \\
\hline Rock outcrop & \multicolumn{2}{|c|}{ Very Low } & \multicolumn{3}{|c|}{2} \\
\hline \multicolumn{6}{|c|}{ Slope $=20 \%$} \\
\hline Level of Slope & \multicolumn{2}{|c|}{ Possibility of sand Encroachment } & \multicolumn{3}{|c|}{ Ranks } \\
\hline $0-1,952,658.89$ & \multicolumn{2}{|c|}{ Very Low } & \multicolumn{3}{|c|}{1} \\
\hline $1,952,658.9-3,626,366.59$ & \multicolumn{2}{|c|}{ Low } & \multicolumn{3}{|c|}{2} \\
\hline $3,626,366.6-5,579,025.49$ & \multicolumn{2}{|c|}{ Medium } & \multicolumn{3}{|c|}{3} \\
\hline $5,579,025.5-8,368,538.29$ & \multicolumn{2}{|c|}{ High } & \multicolumn{3}{|c|}{4} \\
\hline $8,368,538.3-35,566,288$ & \multicolumn{2}{|c|}{ Very High } & \multicolumn{3}{|c|}{5} \\
\hline \multicolumn{6}{|c|}{ NDVI $=15 \%$} \\
\hline Level of Vegetation & \multicolumn{2}{|c|}{ Possibility of sand Encroachment } & \multicolumn{3}{|c|}{ Ranks } \\
\hline$-0.156-0.052$ & & High & & 5 & \\
\hline $0.053-0.085$ & & & & 4 & \\
\hline $0.086-0.128$ & & ium & & 3 & \\
\hline $0.129-0.211$ & & & & 2 & \\
\hline $0.212-0.525$ & & Low & & 1 & \\
\hline & & Rainfall $=7 \%$ & & & \\
\hline $\begin{array}{c}\text { Intensity of Rainfall } \\
\text { (January) }\end{array}$ & $\begin{array}{c}\text { Intensity of Rainfall } \\
\text { (February) }\end{array}$ & $\begin{array}{l}\text { Intensity of Rainfall } \\
\text { (March) }\end{array}$ & $\begin{array}{c}\text { Intensity of Rainfall } \\
\text { (April) }\end{array}$ & $\begin{array}{l}\text { Possibility of sand } \\
\text { Encroachment }\end{array}$ & Ranks \\
\hline $0.400-5.597$ & $1.220-3.205$ & $13.600-22.152$ & $0.000-3.278$ & Very High & 5 \\
\hline $5.598-9.025$ & $3.206-4.719$ & $22.153-30.114$ & $3.279-6.079$ & High & 4 \\
\hline $9.026-13.449$ & $4.720-6.031$ & $30.115-37.192$ & $6.080-8.285$ & Medium & 3 \\
\hline $13.450-19.752$ & $6.032-7.612$ & $37.193-42.795$ & $8.286-10.967$ & Low & 2 \\
\hline $19.753-28.599$ & $7.613-9.799$ & $42.796-51.199$ & $10.968-15.140$ & Very Low & 1 \\
\hline $\begin{array}{l}\text { Intensity of Rainfall } \\
\text { (May) }\end{array}$ & $\begin{array}{l}\text { Intensity of Rainfall } \\
\text { (June) }\end{array}$ & $\begin{array}{l}\text { Intensity of Rainfall } \\
\text { (July) }\end{array}$ & $\begin{array}{l}\text { Intensity of Rainfall } \\
\text { (August) }\end{array}$ & $\begin{array}{l}\text { Possibility of sand } \\
\text { Encroachment }\end{array}$ & Ranks \\
\hline $0.000001-1.235$ & $0-0.596078$ & $0.00000094-5.185$ & $0-3.952$ & Very High & 5 \\
\hline $1.236-2.541$ & $0.596-1.223$ & $5.186-10.508$ & $3.953-7.082$ & High & 4 \\
\hline $2.542-3.988$ & $1.224-1.882$ & $10.509-15.967$ & $7.083-10.129$ & Medium & 3 \\
\hline $3.989-6.035$ & $1.883-2.760$ & $15.968-23.063$ & $10.130-14.741$ & Low & 2 \\
\hline $6.036-8.999$ & $2.761-3.999$ & $23.064-34.799$ & $14.742-20.999$ & Very Low & 1 \\
\hline $\begin{array}{l}\text { Intensity of Rainfall } \\
\quad \text { (September) }\end{array}$ & $\begin{array}{l}\text { Intensity of Rainfall } \\
\text { (October) }\end{array}$ & $\begin{array}{l}\text { Intensity of Rainfall } \\
\text { (November) }\end{array}$ & $\begin{array}{l}\text { Intensity of Rainfall } \\
\text { (December) }\end{array}$ & $\begin{array}{l}\text { Possibility of sand } \\
\text { Encroachment }\end{array}$ & Ranks \\
\hline $0-0.082$ & $0.000-0.696$ & $0.400-1.642$ & NA & Very High & 5 \\
\hline $0.083-0.16$ & $0.697-1.298$ & $1.643-2.150$ & NA & High & 4 \\
\hline $0.17-0.263$ & $1.299-2.108$ & $2.151-2.715$ & NA & Medium & 3 \\
\hline $0.264-0.407$ & $2.109-3.256$ & $2.716-3.562$ & NA & Low & 2 \\
\hline $0.408-0.6$ & $3.257-4.799$ & $3.563-5.199$ & NA & Very Low & 1 \\
\hline
\end{tabular}




\begin{tabular}{|c|c|c|c|c|c|}
\hline \multicolumn{6}{|c|}{ Temperature $=3 \%$} \\
\hline $\begin{array}{c}\text { Intensity of Temperature } \\
\text { (January) }\end{array}$ & $\begin{array}{c}\text { Intensity of } \\
\text { Temperature (February) }\end{array}$ & $\begin{array}{c}\text { Intensity of Temperature } \\
\text { (March) }\end{array}$ & $\begin{array}{c}\text { Intensity of } \\
\text { Temperature (April) }\end{array}$ & $\begin{array}{l}\text { Possibility of sand } \\
\text { Encroachment }\end{array}$ & Ranks \\
\hline $17.100-17.354$ & $18.4-18.615$ & $12.897-15.716$ & $28.402-29.012$ & Very Low & 1 \\
\hline $17.355-17.476$ & $18.616-18.807$ & $15.717-18.360$ & $29.013-29.368$ & Low & 2 \\
\hline $17.477-17.620$ & $18.808-19.007$ & $18.361-20.430$ & $29.369-29.615$ & Medium & 3 \\
\hline $17.621-17.755$ & $19.008-19.2$ & $20.431-21.972$ & $29.616-29.940$ & High & 4 \\
\hline $17.756-17.899$ & $19.3-19.4$ & $21.973-24.087$ & $29.941-30.372$ & Very High & 5 \\
\hline $\begin{array}{c}\text { Intensity of Temperature } \\
\text { (May) }\end{array}$ & $\begin{array}{c}\text { Intensity of } \\
\text { Temperature (June) }\end{array}$ & $\begin{array}{c}\text { Intensity of Temperature } \\
\text { (July) }\end{array}$ & $\begin{array}{c}\text { Intensity of } \\
\text { Temperature (August) }\end{array}$ & $\begin{array}{l}\text { Possibility of sand } \\
\text { Encroachment }\end{array}$ & Ranks \\
\hline $31.858-32.367$ & $34.012-34.452$ & $34.388-35.058$ & $32.104-33.241$ & Very Low & 1 \\
\hline $32.368-32.708$ & $34.453-34.751$ & $35.059-35.669$ & $33.242-34.260$ & Low & 2 \\
\hline $32.709-33.003$ & $34.752-34.998$ & $35.670-36.112$ & $34.261-35.012$ & Medium & 3 \\
\hline $33.004-33.264$ & $34.999-35.233$ & $36.113-36.468$ & $35.013-35.631$ & High & 4 \\
\hline $33.265-33.559$ & $35.233-35.509$ & $36.469-36.900$ & $35.632-36.366$ & Very High & 5 \\
\hline $\begin{array}{c}\text { Intensity of Temperature } \\
\text { (September) }\end{array}$ & $\begin{array}{c}\text { Intensity of } \\
\text { Temperature (October) }\end{array}$ & $\begin{array}{c}\text { Intensity of Temperature } \\
\text { (November) }\end{array}$ & $\begin{array}{c}\text { Intensity of Temperature } \\
\text { (December) }\end{array}$ & $\begin{array}{l}\text { Possibility of sand } \\
\text { Encroachment }\end{array}$ & Ranks \\
\hline $31.841-32.573$ & $28.977-29.446$ & $22.966-23.316$ & NA & Very Low & 1 \\
\hline $32.574-33.137$ & $29.447-29.821$ & $23.317-23.541$ & NA & Low & 2 \\
\hline $33.138-33.503$ & $29.822-30.076$ & $23.542-23.716$ & NA & Medium & 3 \\
\hline $33.504-33.869$ & $30.077-30.337$ & $23.717-23.892$ & NA & High & 4 \\
\hline $33.870-34.364$ & $30.338-30.686$ & $23.893-24.112$ & NA & Very High & 5 \\
\hline \multicolumn{6}{|c|}{ Wind speed $=25 \%$} \\
\hline $\begin{array}{l}\text { Intensity of Wind speed } \\
\text { (January) }\end{array}$ & $\begin{array}{l}\text { Intensity of Wind speed } \\
\text { (February) }\end{array}$ & $\begin{array}{l}\text { Intensity of Wind speed } \\
\text { (March) }\end{array}$ & $\begin{array}{l}\text { Intensity of Wind speed } \\
\text { (April) }\end{array}$ & $\begin{array}{l}\text { Possibility of sand } \\
\text { Encroachment }\end{array}$ & Ranks \\
\hline $6.000-7.482$ & $7.000-8.725$ & $4.915-7.937$ & $7.860-9.342$ & Very Low & 1 \\
\hline $7.483-8.690$ & $8.724-10.105$ & $7.938-9.951$ & $9.343-10.593$ & Low & 2 \\
\hline $8.691-10.200$ & $10.106-11.831$ & $9.952-11.714$ & $10.594-11.820$ & Medium & 3 \\
\hline $10.20-11.545$ & $11.832-13.305$ & $11.715-13.393$ & $11.821-12.944$ & High & 4 \\
\hline $11.546-12.972$ & $13.306-14.999$ & $13.394-15.617$ & $12.945-14.375$ & Very High & 5 \\
\hline $\begin{array}{l}\text { Intensity of Wind speed } \\
\text { (May) }\end{array}$ & $\begin{array}{l}\text { Intensity of Wind speed } \\
\text { (June) }\end{array}$ & $\begin{array}{l}\text { Intensity of Wind speed } \\
\text { (July) }\end{array}$ & $\begin{array}{l}\text { Intensity of Wind speed } \\
\text { (August) }\end{array}$ & $\begin{array}{l}\text { Possibility of sand } \\
\text { Encroachment }\end{array}$ & Ranks \\
\hline $9.990-11.297$ & $10.044-11.070$ & $10.069-11.311$ & $11.189-12.404$ & Very Low & 1 \\
\hline $11.297-12.122$ & $11.071-12.060$ & $11.312-12.281$ & $12.405-13.191$ & Low & 2 \\
\hline $12.123-12.948$ & $12.061-12.982$ & $12.282-13.174$ & $13.192-13.897$ & Medium & 3 \\
\hline $12.949-13.619$ & $12.983-13.729$ & $13.175-13.892$ & $13.898-14.537$ & High & 4 \\
\hline $13.620-14.376$ & $13.730-14.47$ & $13.893-15.017$ & $14.538-15.374$ & Very High & 5 \\
\hline $\begin{array}{c}\text { Intensity of Wind speed } \\
\text { (September) }\end{array}$ & $\begin{array}{l}\text { Intensity of Wind speed } \\
\text { (October) }\end{array}$ & $\begin{array}{l}\text { Intensity of Wind speed } \\
\text { (November) }\end{array}$ & $\begin{array}{c}\text { Intensity of Wind speed } \\
\text { (December) }\end{array}$ & $\begin{array}{l}\text { Possibility of sand } \\
\text { Encroachment }\end{array}$ & Ranks \\
\hline $8.443-9.716$ & $9.001-10.346$ & $7.903-9.129$ & NA & Very Low & 1 \\
\hline $9.717-11.081$ & $10.347-11.103$ & $9.130-10.016$ & NA & Low & 2 \\
\hline $11.082-12.215$ & $11.104-11.823$ & $10.017-10.865$ & NA & Medium & 3 \\
\hline $12.216-13.140$ & $11.824-12.657$ & $10.866-11.695$ & NA & High & 4 \\
\hline $13.141-14.344$ & $12.658-13.831$ & $11.696-12.713$ & NA & Very High & 5 \\
\hline
\end{tabular}

$\mathrm{NA}=$ Data is not available. 
Table A2. Areas and Percentage of sand encroachment during different months.

\begin{tabular}{|c|c|c|c|c|c|c|c|c|}
\hline \multirow{3}{*}{ Months } & \multicolumn{8}{|c|}{ Total Area $=11479 \mathrm{Sq} . \mathrm{Km}$} \\
\hline & \multicolumn{2}{|c|}{ Low } & \multicolumn{2}{|c|}{ Medium } & \multicolumn{2}{|c|}{ High } & \multicolumn{2}{|c|}{ Other } \\
\hline & Sq. Km & $\%$ & Sq. Km & $\%$ & Sq. Km & $\%$ & Sq. Km & $\%$ \\
\hline January & 1448.78 & 12.62 & 6147.45 & 53.55 & 1394.88 & 12.15 & 2487.9 & 21.6 \\
\hline February & 1570.42 & 13.68 & 5937.87 & 51.72 & 1483.89 & 12.92 & 2487.9 & 21.6 \\
\hline March & 1147.36 & 9.99 & 6837.54 & 59.56 & 996.29 & 8.67 & 2487.9 & 21.6 \\
\hline April & 1306.59 & 11.38 & 6621.58 & 57.68 & 1062.96 & 9.26 & 2487.9 & 21.6 \\
\hline May & 1328.92 & 11.57 & 6155.08 & 53.62 & 1507.12 & 13.12 & 2487.9 & 21.6 \\
\hline June & 651.43 & 5.67 & 4989.63 & 43.46 & 3351.12 & 29.19 & 2487.9 & 21.6 \\
\hline July & 672.89 & 5.86 & 4851.51 & 42.26 & 3466.74 & 30.2 & 2487.9 & 21.6 \\
\hline August & 907.99 & 7.91 & 6231.32 & 54.28 & 1852.87 & 16.14 & 2487.9 & 21.6 \\
\hline September & 788.13 & 6.86 & 6163.23 & 53.69 & 2040.81 & 17.77 & 2487.9 & 21.6 \\
\hline October & 742.92 & 6.47 & 6046.74 & 52.67 & 2201.46 & 19.17 & 2487.9 & 21.6 \\
\hline November & 818.63 & 7.13 & 5891.61 & 51.32 & 2281.95 & 19.87 & 2487.9 & 21.6 \\
\hline December & NA & NA & NA & NA & NA & NA & NA & NA \\
\hline
\end{tabular}

\section{Appendix B: Figures of Sand Movement Developed Risk} Zones

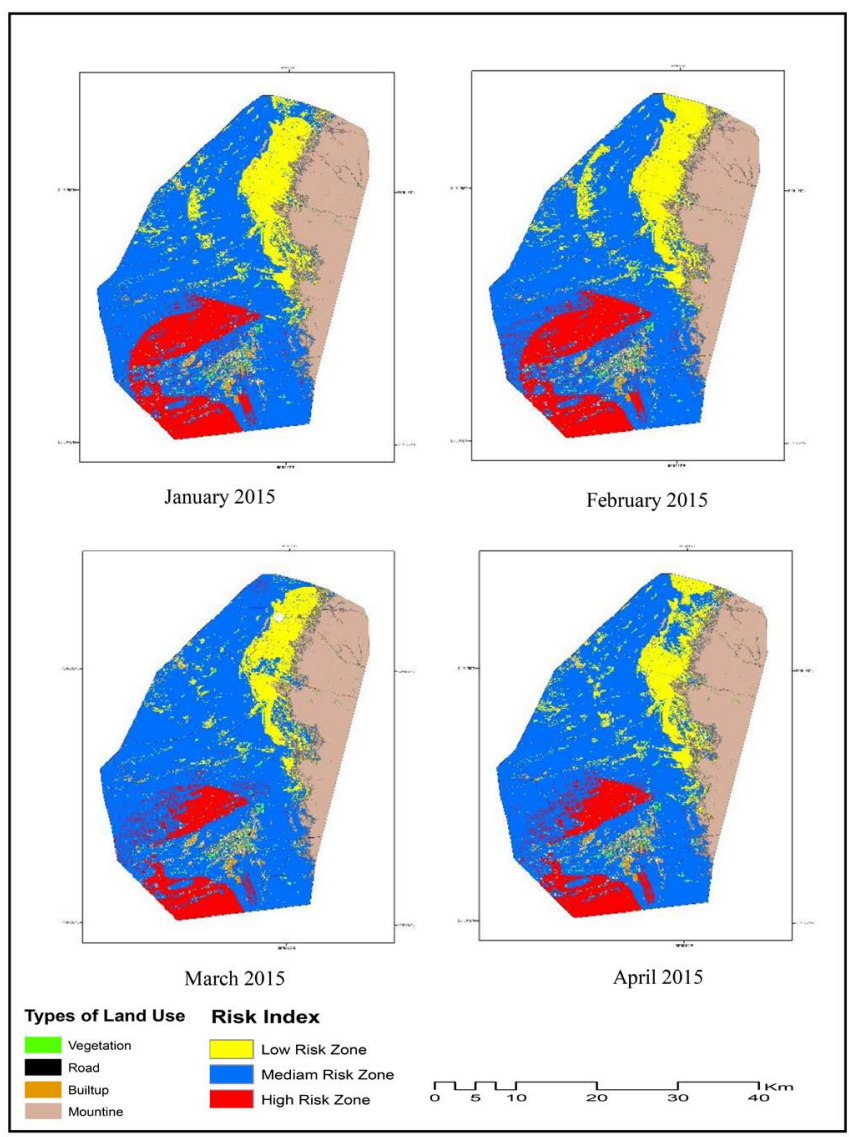



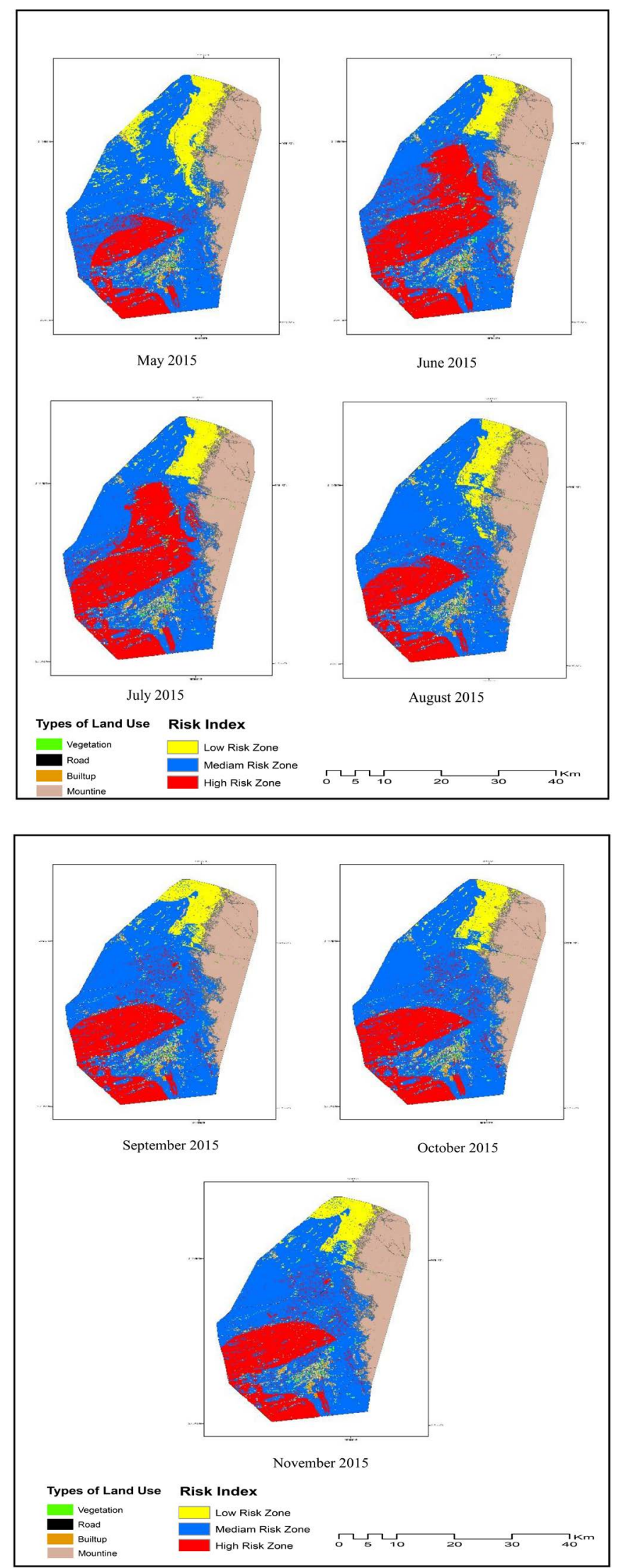

Figure A7. Sand movement developed risk zones (full months). 